\title{
Clitic or Agreement Restriction in Santali: A Typological Analysis
}

\author{
Mayuri J. DILIP \\ Indian Institute of Technology Madras, India \\ mayuri.dilip@gmail.com

\section{Rajesh KUMAR} \\ Indian Institute of Technology Madras, India \\ thisisrajkumar@gmail.com
}

\begin{abstract}
This paper investigates the syntactic configuration of pronominal number marking in Santali. Syntactic, morphological and prosodic restrictions show that pronominal number markers have properties of an affix as well as a clitic. A marker is an affix due to the fact that it cannot participate in a binding relation with other arguments. A pronominal number marker also functions as a clitic since it is attached to prosodically the most prominent constituent. The arguments that trigger object agreement do not manifest one particular case, but instead they indicate a dissociation between case and object agreement. On the other hand, the argument with subject agreement manifests nominative case only, indicating an association between nominative case and subject agreement. Both subject and object agreement are sensitive to case that indicates a property of an affix. Keeping in view the distribution of the pronominal number markers, we analyze feature checking of the two parameters, namely agreement and case in Santali.
\end{abstract}

Keywords: clitic; affix; agreement; prosody; Santali

\section{Povzetek}

Članek proučuje skladenjsko konfiguracijo zaimenskega označevanja števila $v$ santaliju. Skladenjske, oblikoslovne in prozodične omejitve kažejo, da imajo zaimenski označevalci števila lastnosti tako pon (tj. pripon in predpon) kot naslonk. Označevalec deluje kot pona zato, ker ne more stopiti v navezovalno razmerje $z$ drugimi argumenti, kot naslonka pa deluje zato, ker je del prozodično najmočnejšega sestavnika. Argumenti, ki sprožijo ujemanje s predmetom, ne izkazujejo nekega določenega sklona, temveč nakazujejo na razhajanje med sklonom in ujemanjem s predmetom. Po drugi strani pa argumenti, ki sprožijo ujemanje z osebkom, izkazujejo izključno imenovalnik, kar nakazuje na zvezo med imenovalnikom in ujemanjem z osebkom. Tako ujemanje z osebkom kot predmetom je občutljivo na sklon, ki izkazuje lastnost pone. Z vednostjo o distribuciji zaimenskih označevalcev števila $v$ članku analiziramo preverjanje oznak dveh parametrov, ujemanja in sklona v santaliju.

Ključne besede: naslonka; pripona; ujemanje; prozodija; santali 


\section{Introduction}

This paper presents an analysis of pronominal number marking in Santali, which has in previous studies ${ }^{1}$ been discussed either as a clitic (Kidwai, 2005; Anderson, 2007; Hock, 2013, among others) or as an affix/agreement (Subbarao, 2012). We prove that it is the same marker with a combination of affix and clitic features. A typological analysis and application of diagnostic tests show that the pronominal number markers exhibit properties of both clitics as well as affixes. These markers do not depict as two separate morphemes with two different functions, namely a clitic and an affix. Following the application of diagnostic tests, we analyse syntactic configuration of markers, keeping in view the properties of a clitic and an affix. Diagnostic tests reported in Kidwai (2005) show that the subject marker is a clitic in Santali. Additionally, we show that the subject and the object markers also function as affixes. A typological analysis of Khasi, Santali, Hindi-Urdu and Telugu ${ }^{2}$ strengthen our argument that the preverbal position of a subject marker is the locus of a clitic, and that the post-verbal position is the locus of an affix. We notice that the preverbal position of the subject marker in Santali resembles Khasi's preverbal position of the subject marker. The post-verbal position of the subject marker resembles the post-verbal marker in Hindi-Urdu and Telugu. One significant property of affix is its inability to function as a pronoun by showing binding relations with other arguments as mentioned in Baker and Kramer (2016). Such binding relations are absent in Santali. Based on the results obtained from the application of diagnostic tests as in Suñer (1988), Mavrogiorgos (2010), Kramer (2014) and Baker and Kramer (2016), we claim that the subject and object markers syntactically behave like affixes along with their properties of a clitic. Evidence also comes from Hock's (2013) analysis of the subject marker in Santali as a Wackernagel element, where the subject marker attaches to prosodically strongest position within a sentence. This is the preverbal position. Hock's data also mentions the post-verbal occurrence of the subject marker, which is prosodically the weakest position. We consider the marker at the weakest prosodic prominence may be a syntactic locus of an affix based on the evidence obtained from the typological analysis and the application of the diagnostic tests.

The typological analysis of Khasi, Santali, Hindi-Urdu and Telugu shows a diss(association) of agreement and case in Santali. That is, nominative case marked argument obligatorily exhibit subject marking, indicating association. Case apart from

\footnotetext{
${ }^{1}$ Baker (2015, p. 60) citing WALS (Comrie, 2005; Siewierska, 2005b) mentions the status of accusative case marking and object agreement in 188 languages, where 13 out of 188 languages are having both person agreement with the $\mathrm{P}$ argument and accusative case marking: Cahuilla, Comanche, Greek, Guarani, Hungarian, Kanuri, Koasati, Kunama, Mangarayi, Miwok, Persian, Quechua, and Spanish. Among the languages mentioned above, the object agreement marker is probably a clitic and not true agreement as in Spanish and Greek.

${ }^{2}$ The data in Telugu is provided by the author of this reasearch, who is a native speaker of Telugu. The sentences are grammatical and acceptable to the best of the author's knowledge.
} 
nominative, typically those which remain VP internally may or may not co-occur with object marking, indicating dissociation. Both subject and object agreement are sensitive to case. Keeping in view the results obtained from the investigation, we analyse the affix-clitic phenomenon of Santali by adopting Woolford's (2006) case system; feature interaction as in Davison (2004); movement of noun to higher $D^{0}$ to handle the (in)animates as in Kidwai (2005); Bhatt's (2005) AGREE to analyze the (diss-)association of case and agreement; finally, the Prosodic Inversion (Halpern 1992, Taylor 1995) to analyze the markers at prosodically strongest position.

The organization of the paper is as follows: section 2 discusses the basic description of pronominal number marking in Santali, and a typological analysis of select South Asian languages with a special focus on Santali; section 3 demonstrates the results of diagnostic tests, which show the role of a pronominal number markers as a clitic as well as an affix; section 4 elaborates the phrase structure in Santali, keeping in view the clitic-affix properties of subject and object markers; and finally, section 4 makes an overall conclusion.

\section{Morphological description of the pronominal number markers}

In this section, we demonstrate the morphological distribution of pronominal number markers in Santali (see Appendix A for the list of markers). Firstly, we provide a basic description of a subject marker (SM) and an object marker (OM) that correspond to various arguments such as subject, direct object (DO), indirect object (IO), object indicating possessor, object indicating beneficiary and non-nominative subject (NNS). We compare the pronominal number markers among Santali, Khasi, Hindi-Urdu and Telugu in order to identify their structural interaction with other syntactic operations such as case and agreement. Finally, the results of the diagnostic tests show that SM and OM have properties of an affix as well as a clitic. We also show how the evidence obtained from the typological analysis is parallel to the results obtained in the diagnostic tests.

\subsection{Canonical structure of agreement in Santali}

In this section, we discuss the basic structure of pronominal number markers in Santali. The SM $-y$ occurs to the right and the OM -e occurs to the left of the finiteness marker $-a$ in (1) and (2). Alternatively, SM is attached to the preverbal constituent gidra as in $(2 b)^{3}$. An OM is absent from an intransitive verb as in (2a).

\footnotetext{
${ }^{3}$ See example (8) in section 3.1 for sentences with subject marking.
} 
(1) arel $_{i}$ uni $i_{j}$ nel-ked-e $e_{j}-(y) a-y_{i} \quad$ (Santali)

Arel him see-PST:A-OM-FIN-SM

'Arel saw him.'

(2a) gidrai udgoro?-kan-a-yi (Santali)

child sweat-COP.PST-FIN-SM

'The child was sweating.'

(2b) gidra-yi udgoro?-kan-a (Santali)

child-SM sweat-COP.PST-FIN

'The child was sweating.'

Arguments such as object indicating possessor, object indicating beneficiary and NNS exhibit OM within the verb as in (3) (Neukom, 2001, pp. 111-112). The OM of the object indicating possessor is preceded by $-t$, a possessor incorporation as in (3a). The $\mathrm{OM}$ of the object indicating beneficiary is preceded by the applicative $-a$ - as in (3b). The NNS in a psych-predicate exhibits OM as in (3c).

(3a) baha in-ak dal-t-in-a-e (Santali)

Baha I-GEN strike-POSS-OM-FIN-SM

'Baha will strike mine.'

(3b) baha in-renak dal-a-in-a-e (Santali)

Baha I-for strike-APP-OM-FIN-SM

'Baha will strike for me.'

(3c) baha $_{i}$ rabay nam-akad-e(y) $)_{i}-a$ (Santali)

Baha.NNS cold.NOM OBJ have-PRF:A-OM-FIN

'Baha caught cold.'

In (4a), puthi 'book' is an inanimate noun, and therefore the corresponding OM ( $\varnothing)$ does not realise. In a ditransitive sentence the DO takes precedence over the $\mathrm{IO}$ as in (4b) when both DO and 10 are animate. ${ }^{4}$ If one among DO or 10 is animate, then the $\mathrm{OM}$ of the object with animate features realizes on the verb as in (4c).

\footnotetext{
${ }^{4}$ Baker (2012, p. 257) and also Leslau (1995, p. 186) show example from Amharic where the higher object (goal) among the two objects agrees within the ditransitive sentence. This property of the goal is a feature of object agreement and not cliticization. Such property of the goal does not exist in Santali. Instead, among the patient and the goal, it is the patient which realizes as the object marking in Santali.
} 
(4a) arel $_{i}$ puthi nel-ked- $\varnothing-a-y_{i}$

(Santali)

Arel book see-PST:A-[-OM]-FIN-SM

'Arel saw the book.'

(4b) baha $_{i}$ arel gidra-kin ${ }_{j} \quad$ ema-t-kin $n_{j}-a-y_{i} \quad$ (Santali)

Baha.SUBJ Arel IO child-dual DO give-PST:A-OM-FIN-SM

'Baha gave the (two) children to Arel.'

(4c) baha $_{i} \quad$ gidra-kin $_{j} \quad$ potsb ema-t-kin ${ }_{j}-a-y_{i} \quad$ (Santali)

Baha.SUBJ child-dual.10 book.DO give-PST:A-OM-FIN-SM

'Baha gave the book to the (two) children.'

The patient in a transitive sentence is accusative case marked and it possesses object marking as in (5a). If the same sentence is passivized, the patient is nominative case marked and it possesses subject marking as in (5b). Therefore, subject/object marking is sensitive to case as well as thematic roles. The markers being sensitive to other grammatical operations shows that we have a requirement to observe other grammatical operations in order to identify the true nature of the markers. Therefore, in the following section, we observe a typological analysis of the pronominal number markers among Khasi, Santali, Telugu and Hindi-Urdu.

(5a) arel $_{i}$ uni $_{j} \quad$ nel-ked-e $\boldsymbol{e}_{j}-(y) a-\boldsymbol{y}_{i} \quad$ (Santali)

Arel him.patient see-PST:A-OM-FIN-SM

'Arel saw him.'

(5b) $\mathbf{u n i}_{i}$ arel-țhen nel-oco-en- $\boldsymbol{a}-\boldsymbol{y}_{\boldsymbol{i}}$ (Santali)

he Arel-by see-PASS-FIN-SM

'He was seen by Arel.'

In the following section, we provide a comparison of subject/object marking in Santali with the agreement structure of selected South Asian languages.

\subsection{Variations and commonalities of agreement in Santali, Telugu, Hindi-Urdu and Khasi}

Recall that the previous studies mention pronominal number marker as either a clitic or an affix in Santali. However, it was never considered as a marker with both of the features. The typological analysis of pronominal number markers shows that Santali contains features of Austro-Asiatic as well as non-Austro-Asiatic languages. In other words, the markers are combinations of affix-like and clitic-like properties. The 
typological analysis is elaborated below. One parallel among Khasi and Santali is the preverbal placement of SM. That is, $u$ in Khasi occurs after la wan 'came' as in (6a) and $-y$ in Santali occurs after nelkedeya 'saw' as in (6b). The variation between Khasi and Santali is that the SM in Khasi never occurs post-verbally. In contrast, the SM in Santali occurs post-verbally as in (6c). The object marking precedes the finite marker $-a$ as in (6b) and (6c). In contrast, object marking is absent in Khasi, Hindi-Urdu and Telugu ${ }^{5}$. The analogy between Telugu, Hindi-Urdu and Santali is the post-verbal occurrence of SM as in (6c) to (6e). That is, the SM -y in Santali, $-i$ in Hindi-Urdu and -di in Telugu attach to the right of the verb. In Section 3, we provide evidence to show that the preverbal occurrence of SM is the locus of a clitic, and the post-verbal occurrence is an affix.

(6a) u briew u la wan (Khasi)

M. human M. PST come

'A man came.' (Nagaraja, 1993)

(6b) arelj unij-y nel-ked-e $\boldsymbol{i}_{-}-(y) a \quad$ (Santali)

Arel him-SM see-PST:A-OM-FIN

'Arel saw him.'

(6c) arel $_{j}$ uni nel-ked-e $_{i}-(y) a-y \quad$ (Santali)

Arel him see-PST:A-OM-FIN-SM

'Arel saw him.'

(6d) rāmuḍu sìta-ni cūs-ā-ḍu (Telugu)

Ram Sita-ACC see-PST-3.SG.M

'Ram saw Sita.'

(6e) $u m \bar{a}$

kamīz lāì

(Hindi-Urdu)

Uma.NOM shirt bring.PST.F

'Uma brought a shirt.' (Koul, 2008, p. 38)

The experiencer pallavi has overt dative case marking: $-k i$ in Telugu and $k o$ in HindiUrdu as in (7a) and (7b). In contrast, the OM $e$ of the experiencer attaches the verb as in (7d). In the three languages mentioned above, the logical subject pallavi in Hindi-

\footnotetext{
${ }^{5}$ Irrespective of Santali, Hindi-Urdu and Telugu, and belonging to three different language families, they show commonalities. Such commonalities can besides be found in Hindi-Urdu and Icelandic, where they have quirky subjects/non-nominative arguments possessing all the properties of a subject except with the verbal agreement. Similarly, the nominative object possesses all the object properties except the verbal agreement (Thaínsson, 1979, p. 466). According to Subbarao (2012), the non-nominative experiencers have less probability to trigger verbal agreement.
} 
Urdu/Telugu and baha in Santali exhibit object-like property. However, the mechanism exhibiting the object-like property in Hindi-Urdu/Telugu is different from Santali. That is, the NNS exhibits overt case marking in Hindi-Urdu/Telugu and object agreement in Santali. We consider the overt case marking and object agreement as object-like properties since they also occur on arguments such as direct and indirect objects. These are the arguments that do not move out of the verbal complex v/VP for case. The point that we emphasize is that the underlying syntactic interactions of NNS are same in all the three languages irrespective of the variations at the morphological level. Since, the underlying structure is similar to Hindi-Urdu/Telugu, we assume that the operations in Santali that are similar to Hindi-Urdu/Telugu may determine the affix-like properties of OM. In section 3, the application of the diagnostic tests shows that OM has some properties of an affix, apart from its properties of a clitic.

In (7a) and (7b), another parallel among Hindi-Urdu and Telugu is the nominative case and verbal agreement of theme khuši (Hindi-Urdu) and jvaram (Telugu) in psychpredicate. We assume that the theme has nominative case in Santali also. In South Asian languages as in (7), the subject agreement and nominative case obligatorily cooccur. Therefore, we consider such co-occurrence as a diagnostic test to determine whether or not the argument in a nominative case is marked. However, there is no evidence to show that the theme is not marked as a nominative case since the argument is inanimate, and as a result, SM is absent as in (7c).

Khasi $^{6}$ does not have constructions with experiencer subjects (Subbarao 2012: 12) and therefore we cannot show a comparison with Santali.

(7a) pallavi-ki $i_{i}$ jvaram $_{j} \quad$ vacc-in-di $i_{j} \quad$ (Telugu)

Pallavi-DAT cold.theme come-PST-3.SG.M

'Pallavi got fever.'

(7b) allavi ko bahut khušs $\bar{l}_{j} \quad$ huī $*_{i, j} \quad$ (Hindi-Urdu)

Pallavi DAT very happiness.theme happened

'Pallavi felt very happy.' (Subbarao, 2012, p. 147)

${ }^{6}$ In Khasi the sentence where the experiencer subject does not show any object-like properties as in (i) is possible.

(i) $u$ john u don jingshit

$\mathrm{m}$ john $\mathrm{m}$ has fever

'John has a fever.'

(Personal communication with Marshall Kharumnuid, Indian Institute of Technology Madras) 

(7c) $b^{2} a_{i}$ raban nam-akad-e $\boldsymbol{e}_{i}-a \quad$ (Santali)
Baha cold.theme have-PRF:MID-OM-FIN
'Baha caught cold.'

In the following section, we demonstrate the properties of a clitic and an affix in Santali based on the diagnostic tests.

\section{Pronominal number marker: clitic vs. affix}

In this section, we demonstrate that subject/object marker has both the properties of a clitic and an affix. We strengthen the fact mentioned above with the evidence obtained from the diagnostic tests.

\subsection{Pronominal number markers depicting clitic-like properties}

Kidwai (2005) provides evidence that the subject/object marker is a clitic. The evidence is the following:

1. Markers have a high degree of selection with respect to hosts, as they can attach to nouns, postpositions, negation, verbs and light verbs.

2. Markers do not have unexplained gaps. For example, in English, the kinship terms are fatherly, daughterly, motherly, but not *sonly. Such gaps are not possible in Santali.

3. Idiosyncratic semantics does not exist with these markers. For example, -er in revolver vs. dancer in English.

4. Markers do not undergo stem allomorphy or other morphological idiosyncrasies. For example, the morphological idiosyncrasies as in slap, give and see in English.

5. A marker has the ability to move.

6. The clitics attach after the markers of functional categories. Based on the evidence obtained from the data showing that the marker is a clitic, Kidwai argues that the clitics are copies of number marking that fail to delete and they occur as Backernagel (P-2) analysis. In the analysis, the animate NPs are [+R] featured indicating that they are referential expressions possessing [PERSON] feature and as a result, they undergo the operation MOVE involving COPY +MERGE. Following MOVE, a copy of the pronoun is left in the $\mathrm{N}^{0}$. The stranded [NUMBER] featured pronominal copy at the level of PF is not eligible to get deleted and as a result it realizes into a number morpheme. Inanimate nouns have a structure similar to Bhattacharya's (1999) analysis of deixis indicating location such as that ${ }^{\text {DISTAL, }}$ 
that ${ }^{\text {REMOTE }}$ and this, where they occur lower than $\mathrm{D}^{0}$. As a result, the inanimate noun undergoes operations such as COPY+ MERGE.

Hock's (2013) analysis of SM provides evidence that markers have a combination of affix-like and clitic-like properties. According to Hock (2013, p. 70), the SM is a Wackernagel element (P-2). That is, subject markers occur on any constituent to the left of the verb if they are prosodically dominant, as in (8). They occur preverbally since they are in the FOCUS position. The preverbal marker is a unique feature in Santali, which differs from other non-Austro-Asiatic languages. Alternatively, P-2 occurs postverbally as in (9). The post-verbal position has the weakest prominence in the utterance. Hock also mentions Osada's (2008) observation that the younger speakers mostly prefer the post-verbal position ${ }^{7}$. In our analysis, we consider the post-verbal occurrence of the SM as an affix and not cliticization since its occurrence is not based on prosodical prominence. One more indication that SM may be an affix is its resemblance with the post-verbal occurrence of SM in Hindi-Urdu and Telugu as in section 2.1.

(8a) $a b u$ hola sinema nel-lagit=bun calaw-len-a (Santali)

we.INCL. yesterday cinema see-APP.=we.INCL. go-PST-FIN

'We had gone to see the movie yesterday.' (Kidwai, 2005)

(8b) abu hola=bu sinema nel-lagi[t] calaw-len-a (Santali)

we.INCL. yesterday=we.INCL. cinema see-APPL. go.PST-FIN

'We had gone to see the movie yesterday.'

${ }^{7}$ Givón (1976) on the other hand, 'the NP-detachment hypothesis', where the pronouns are reanalysed as affixes in three stages such as the following.

Stage I. Analytic pronoun argument agrees with a dislocated NP.

$\begin{array}{llll}\text { (Marie } i) & \text { she }_{i} & \text { like } & \text { strawberries. } \\ \text { ADJUNCT } & \text { SUBJECT } & \text { VERB } & \end{array}$

Stage II. Incorporated pronoun agrees with a dislocated NP.

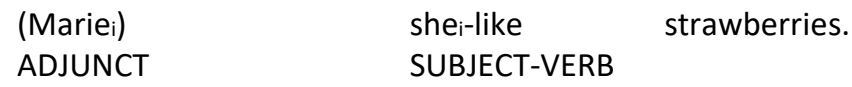

Stage III. Grammatical agreement marker agrees with subject NP.

Marie 3SG.FEM-like strawberries.

SUBJECT AGR-VERB

If we compare the structures as in (8a) with San tali, we find structure as in stage III only, where the marker's phonetic form resembles partially to the pronouns in Santali (See appendix 1 for the list of pronouns). It is our assumption that the pronoun preceding the verb might have undergone a transformation from a pronoun as in stage II to a bound morpheme as in stage III. 

(8c) $a b u=b u \quad$ sinema nel-lagit calaw-len-a (Santali)
we.INCL=we.INCL. cinema see-APPL. go-PST-FIN
'We had gone to see the movie.' (Kidwai, 2005)

(9) $n \varepsilon l-g t^{\prime}-k a-t^{\prime}-k o-a=k o$

(Santali)

see-EMPH-COMPLASP-TR.3PL-FIN=3PL

'They saw them off.' (Anderson, 2007, p . 245)

\subsection{Pronominal number markers depicting affix-like properties}

Applications of the diagnostic tests of Suñer (1988), Mavrogiorgos (2010), Kramer $(2014)^{8}$ and Baker and Kramer (2016) among others, show that the pronominal number markers are affixes.

Mavrogiorgos (2010, p. 98) states that a subject triggers agreement and an object cliticizes. One reason is that a subject refers to one case role only (nominative) while an object depicts more than one case role (genitive, accusative and nominative). That is, a clitic co-indexes an argument irrespective of its case-marking. In Santali, the subject depicts only one case (nominative) and therefore, SM as an affix. The OM at first glance may behave like a clitic, due to variation in case features of corresponding objects. If we observe the objects, the OM co-indexes only to those arguments which achieve case within the verbal complex and as a result, they are eligible to co-index with an OM. Therefore, OM is sensitive to case similar to an SM.

The absence of subject/object marker due to semantic features such as specificity, animacy or definiteness is a feature of a clitic (Sũner, 1988) ${ }^{9}$. According to Corbett (2006, pp. 14-15), optional marking is the nature of a clitic. In other words, the

\footnotetext{
${ }^{8}$ Kramer (2014, p. 5) mentions three approaches to analyse an OM such as i. The OM involves in feature checking; ii. OM is a morpheme that moves into the verbal complex from within the DP; iii. A combination of both the analyses mentioned above. Kramer's analysis of clitic doubling involves the option (iii). That is, Agree relationship between $v$ and doubled clitic, A-movement (Nevins, 2011; Harizanov, 2014) of DP/D to [spec, vP] and finally m-merger (Matushansky, 2006) with v. We cannot adopt this analysis for Santali since the method of A-movement is suitable if the subject/object markers show any properties of pronouns syntactically indicating that the markers are clitics. However, the diagnostic tests show that the markers do not have the properties of a pronoun.

${ }^{9}$ Suñer (1988) shows clitic doubling in Spanish where the doubling takes place only when the object is [+specific +animate] as in (i) and (ii). The optionality is shown as a property of a clitic.

(i) La oian a Paca/ a la niña/a la gata

Her 3.PL-listened to Paca/ the girl/the cat [+anim, +spec, (+def)]

'They listened to Paca/the girl/the cat.'

(ii) * La compramos (a) esa novella.

It-F1.PL-bought that novel [-anim, +spec, (+def)]

'We bought that novel.'
} 
agreement marking is obligatory for all the DPs irrespective of the semantic features. In Santali too, subject/object markers are absent if the argument is inanimate as in (10a) indicating clitic-like property. However, $\mathrm{OM}$ is sensitive to case along with animacy in a ditransitive sentence with animate DO and animate $1 O$ as in (10b). In this context, the $\mathrm{OM}$ of the $\mathrm{DO}$ realizes within the verb and not an IO, irrespective of IO being animate. Therefore, the object marking being sensitive to case is a necessary condition along with animacy feature.

(10a) areli puthi $i_{j}$ nel-ked- $\varnothing_{j}-a-y_{i}$ (Santali)

Arel book see-PST:A-TR- $\varnothing-$ FIN-SM

'Arel saw the book.'

(10b) baha $_{i} \quad$ arel gidra-kin ${ }_{j} \quad$ ema-t-kin ${ }_{j}-a_{-} y_{i} \quad$ (Santali)

Baha.SUBJ Arel IO child-dual DO give-TR-OM-FIN-SM

'Baha gave the (two) children to Arel.'

If $O M$ is an affix, it is entirely absent in passive and/or reflexive verbs (Kramer 2014). ${ }^{10}$ In Santali too, the nominal reflexive in (11a) and the 10 in a passive sentence in (11b) do not exhibit OM attached to the verb. ${ }^{11}$

(11a)
pețue-koi akotege-ko;
sarhao-en-(*ko)-a
(Santali)
student-PL by themselves-SM praise-PST:MID-(*OM)-FIN

'The students praised themselves.'

\footnotetext{
${ }^{10}$ Baker and Kramer (2016) provide a different analysis of reflexives, where the absence of clitic doubling of a reflexive anaphor is a diagnostic test of a clitic. We do notice the absence of clitic with a reflexive in Santali. However, we consider the absence of the clitic is not due to the crossover effects, but due to the detransitivizing property of a verb depicting anaphoric relationship. A similar property of detransitivizing can be observed in passive sentences, sentences with reciprocal anaphors, sentences with self-benefactive marking and intransitive sentences. If the absence of the object clitic is due to crossover effect, its effect would have been found in interrogative NPs and/or universally quantified NPs also, which is not the case in Santali. In other words, the PNS occurs with interrogative NPs and universally quantified NPs without crossover effects.

${ }^{11}$ The OM in Amharic shows a different structure from Santali, where the clitic doubling takes place for passives and reflexives as in (i) and (ii). Therefore, the marker in Amharic is a clitic and not an affixes.

(i) älmaz mäx'haf-u tä-sät't'-at

Almaz.F book-DEF.M PASS-give-(3MS.S)-3FS.0

'The book was given (to) Almaz.' (Baker, 2014, (16b); Kramer, 2014, p. 16)

(ii) idd3d3-wa-n t-at't'äb-äftf- iw

hand.M-her-ACC REFL-clean-3FS.S-3MS.0

'She washed her hands.' (Leslau, 1995, p. 464; Kramer, 2014, p. 16)
} 


\title{
(11b) larhai-re asok hotete aḍihore got-akan-(*ko)-a (Santali) \\ war-in Ashok by many people kill-PRF:M-(*OM)-FIN \\ 'Many people were killed by Ashok in the war.'
}

According to Baker and Kramer (2016) ${ }^{12}$, an OM is a clitic, if it does not co-occur with anaphoric DPs, quantified DPs containing a bound variable and interrogative pronoun. ${ }^{13}$ This is because the marker functions as an intervener preventing any movement operations. In Santali, the presence of subject/object markers does not interrupt the binding relation between the antecedent baha and the verbal reflexive $n$ - /nije-lagit as in (12) and (13). The absence of OM is not due to its function as an intervener, but due to the intransitive nature of the verb. Such intransitive nature of the verb and the non-existence of $\mathrm{OM}$ is also found in intransitive, self-benefactive and passive verb as in (14).

(12) bah
baha arsi-re nel-en-a-y
(Santali)
Baha mirror-in see-PST.MID-FIN-SM

'Baha saw herself in the mirror.'

(13) baha nije-lagit gudiya-ko kirin-ket-ko-a-y

(Santali)

Baha self-for doll-PL buy-PST:A-OM-FIN-SM

'Baha bought dolls for herself.'

\begin{abstract}
12 The diagnostic text with an interrogative pronoun cannot be applied to Santali since the whelement occurs in-situ as in (i). We cannot show the interaction of the pronominal number markers with the wh-element since wh-movement does not exist in Santali. In Amharic, the presence of the clitic prevents wh-movement as in the sentence (1), footnote (20).
\end{abstract}

(i) uni ayo jete hor dular-ko-a-y (Santali)

his mother everyone love.HAB-OM-FIN-SM

'His mother loves everyone.'

${ }^{13}$ The following are the constructions (Baker \& Kramer, 2016, p. 4) with interrogative NP, universally quantified NP and reflexive anaphor in Amharic and the OM cannot occur in these constructions.

(i) Mann- in ayy- if? (*ayy- if-iw)

who.M-ACC see.PH-2FS.S see.PF-2FS.S-3MS.O

'Who did you (feminine) see?'

(ii) Lämma hullu-n-imm säw ayy-ä. (*ayy-äw)

Lemma.M-ACC person see.PF-3MS.S see.PF(3MS.S)-3MS.O

'Lemma saw everyone.'

(iii) Lämma rasu-u-n gäddäl-ä. (*gäddälä-w)

Lemma.M self-his-ACC kill-3MS.S kill(3MS.S)-3MS.O

'Lemma killed himself.' 
- $n$ - playing a role of intransitive marker.

(14a) baha arel sala ragi-len-a (Santali)

Baha Arel with anger-PST:MID-FIN

'Baha was angry with Arel.'

- $n$ - playing a role of self-benefactive marker.

(14b) baha ub' get'-en-a-y (Santali)

Baha hair cut-PST:MID-FIN-SM

'Baha cut her hair.'

- $n$ - playing a role of a passive marker.

(14c) kumbdu polis then sap-oco-len-a-y

(Santali)

Thief police with catch-PASS-PST:MID-FIN-SM

'The thief was caught by the police.'

Summing up the discussion, pronominal number markers in Santali realize animacy, person and number features but not grammatical gender. SM attaches to preverbal constituents; to any constituent to the left of the verb, or else it attaches post-verbally. $\mathrm{OM}$ attaches to the left of the finiteness marker of a verb. Pronominal number marking for inanimate nouns is absent. In the case of a ditransitive sentence, when both DO and $\mathrm{IO}$ are animate, it is the OM of DO that attaches to the verb. However, when one among the objects is inanimate, the animate object exhibits object marking. In psych-predicate, the NNS exhibits OM. The evidence obtained from a typological analysis, the application of diagnostic tests and Hock's (2013) analysis of SM show that the pronominal number markers have properties of both a clitic and an affix.

Santali shows the preverbal occurrence of SM similar to Khasi and post-verbal occurrence of SM as in Hindi-Urdu and Telugu. Kidwai's (2005) diagnostic tests show that they are clitics since they have a high degree of selection of hosts; unexplained gaps of SM are absent; idiosyncratic semantics of the markers do not exist; the markers do not undergo stem allomorphy; the SM has the ability to move; the marker attaches to the functional categories.

Apart from Kidwai's findings, another feature that reflects a clitic-like property is its nature to be sensitive to animacy. Hock's (2013) observation of SM provides us evidence that there is a possibility for SM to have properties of both affix and a clitic. According to Hock, SM is a Wackernagel element, where the marker attaches to the constituent with highest prosodical prominence. Alternatively, SM occurs post-verbally, which is prosodically the least prominent position. The post-verbal occurrence of the SM attaching the least prominent position might be the position of subject agreement. 
Diagnostic tests as in 3.2 show the following results:

1. Pronominal number markers is not optionally dropped in the presence of DO, since pronominal number markers do not function as in intervener.

2. The occurrence of pronominal number markers is restricted to case properties. That is, SM occurs only with nominative arguments and OM occurs only with arguments that are case-marked within the verbal complex.

3. OM is absent for passives and reflexive verbs.

4. Pronominal number markers do not function as an intervener for anaphoric DPs.

5. The $\mathrm{OM}$ of animate $\mathrm{IO}$ does not realize since the $\mathrm{OM}$ is sensitive to case, where the DO takes precedence over the IO.

In the following section, we discuss the syntactic configuration of pronominal number markers, keeping in view properties of an affix and a clitic.

\section{Syntactic analysis of pronominal number markers}

Keeping in view the restrictions of the pronominal number markers, we demonstrate the syntactic configuration of these markers. The analysis involves (non-)structural case licensing as in Woolford (2006); feature checking of case and agreement as in Davison (2004); analysing (diss-)association of agreement and case by adopting Bhatt (2005); distinguishing inanimates from animates, where animates move to a higher position $D^{0}$ as in Kidwai (2005). Finally, Prosodic Inversion as in Halpern (1993) in order to analyse the SM occurring in the prosodically prominent position.

The syntactic configuration can be presented in four steps. The first three steps are at LF while step 4 is at PF.

a. Step 1 shows the (non-)movement of a noun to higher $D^{0}$ within $D P$, depending upon the animacy feature of a noun.

b. Step 2 is feature checking of case.

c. Step 3 is feature checking of agreement, where agreement depends upon the position of the argument in a tree structure. It occurs as a consequence of steps (1) and (2) since the presence or absence of agreement and the type of agreement (subject or object) depends on the movement of the animate noun to a higher position within DP and also the location of the argument within or outside the verbal complex.

d. Step 4 is prosodic inversion. 


\subsection{Step 1}

One of the properties of a clitic is the absence of pronominal number marker due to the inanimate feature of the argument. In contrast, the marker is present when the argument is animate as in (4a) in section 2.1, repeated in (15). The absence of the marker is indicated by $\varnothing$. In line with Kidwai (2005: 203), the inanimates are not real pronominals because they do not refer to pronominals indicating person features. Instead, they refer to deixis of location such as that ${ }^{\mathrm{DISTA}}$, that ${ }^{\mathrm{REMOTE}}$ and this. Hence, Kidwai shows a representation as in (16), where an inanimate noun originates at $\mathrm{N}^{0}$ within NP and it does not have the ability to move to a higher position $D^{0}$ as in (16a). As a result, an inanimate noun is ineligible to participate in agreement due to its embeddedness within the DP. In contrast, an animate noun originates at $\mathrm{N}^{0}$ within NP and it moves to $D^{0}$ as in (16b).

(15) areli puthi nel-ked- $\varnothing-a-y_{i}$

(Santali)

Arel book see-PST:A-[-OM]-FIN-SM

'Arel saw the book.'

(16a)

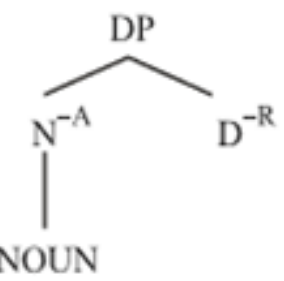

(16b)

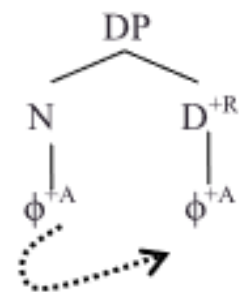




\subsection{Step 2}

Adopting Woolford $(2006)^{14}$, verbal complex in Santali depicts the theta discharge of external argument (an agent or an experiencer ${ }^{15}$ ) at the higher [spec, vP], DP goal/recipient ${ }^{16}$ at lower [spec, vP] and the theme/internal argument as the complement of $\mathrm{V}$ as in (17). We label the higher $\mathrm{VP}$ as $\mathrm{V}_{1} \mathrm{P}$ and the lower $\mathrm{VP}$ as $\mathrm{V}_{2} \mathrm{P}$ for the sake of convenience. The theta-discharge takes place right where they are basegenerated. Consequently, the agent moves to [spec, TP] to check nominative case. In psych-predicates, a theme moves to [spec, TP] to check nominative case.

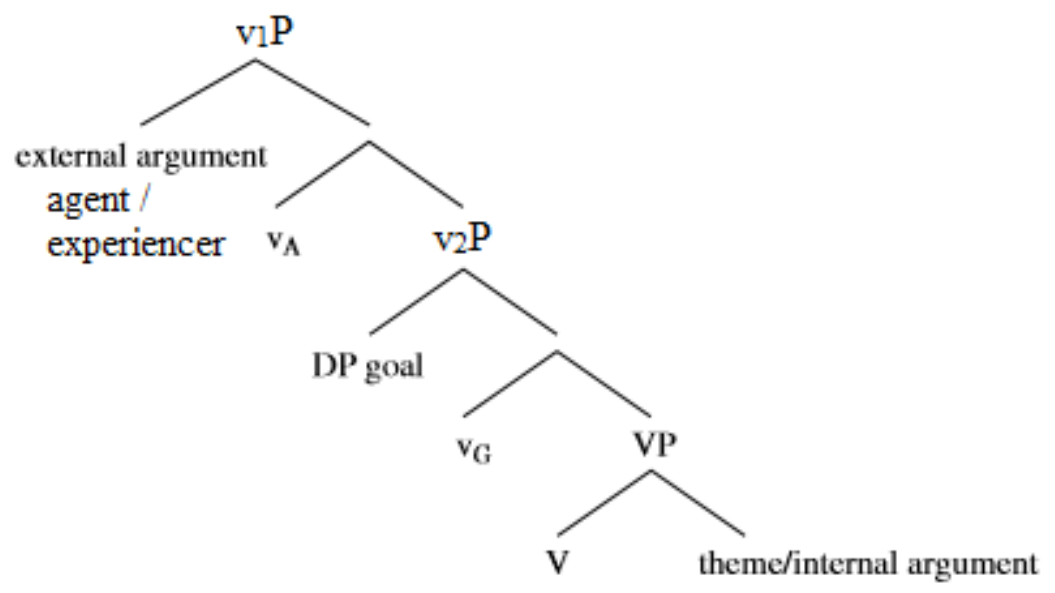

Tense and $\mathrm{V}$ function as goals with interpretable case features. The interpretable features of tense include nominative case, subject agreement and EPP. Interpretable features of $V$ include structural accusative case and object agreement. The

\footnotetext{
${ }^{14}$ Woolford classifies non-structural case into lexical and inherent case. Lexical case is idiosyncratic; lexically selected by an individual verb or preposition. It is associated with the internal argument such as theme/internal arguments, case-marked arguments such as dative on ditransitive goal and not on (shifted) DP arguments. These arguments are checked by V in the VP proper.

Inherent case is associated with arguments external to the VP such as agent/external arguments (ergative case) and on (shifted) DP arguments, which are the positions with higher $\theta$-roles. These arguments are checked by little/light $v$ within $v P$. The inherent case is associated with specific $\theta-$ roles.

${ }^{15}$ Davison's concept of equidistance to TENSE is not suitable for Santali since the equidistance creates equal rights for the experiencer as well as the theme to achieve case, agreement and EPP of TENSE. However, the features of TENSE are unequally distributed among the arguments. That is, the experiencer receives only EPP feature from $T$ and the rest of the features such as the nominative case and agreement are provided to the theme. However, note that the theme is ineligible to receive agreement features due to inanimate feature.

${ }^{16}$ Davison (2004) provides a v/VP structure where the IO/goal occurs within VP. In Santali, IO within $V P$ is not required since the lower $V$ has no role in providing lexical case to IO. Instead, the argument is checked lexical dative case by its null $P$ in Santali.
} 
interpretable feature of $\mathrm{v}$ is lexical case. Arguments function as probes with uninterpretable unvalued case features. Feature checking of case is elaborated below.

In intransitive, transitive and ditransitive sentences as in (2a), (5a) and (4b) in section 2.1, repeated in (18) below, agent/subject originates at [spec, $\mathrm{v}_{1} \mathrm{P}$ ] (in italics) and moves to [spec, TP]. Consequent to movement, $\mathrm{T}^{0}$ checks nominative case and EPP with the agent as in (19).

$$
\begin{aligned}
& \text { gidra } a_{i} \quad \text { udgoro?-kan-a- } y_{i} \quad \text { (Santali) } \\
& \text { child.agent sweat-COP.PST-FIN-SM }
\end{aligned}
$$

'The child was sweating.'

(18b) arel $_{i}$

$$
\text { uni } i_{j} \text { nel-ked-e } \boldsymbol{e}_{j}-(y) a-y_{i} \quad \text { (Santali) }
$$

Arel.agent him see-PST:A-OM-FIN-SM

'Arel saw him.'

(18c) baha $_{i}$

arel

gidra-kin

ema-t-kin $n_{j}-a-y_{i}$

(Santali)

Baha.agent Arel.recipient child-dual.patient give-PST:A-OM-FIN-SM

'Baha gave the (two) children to Arel.'

(19) Before: [Tp agent.probe $\left[T^{\prime} T^{0} .{ }_{\text {GOAL }}[\mathrm{v1P} \ldots\right.$.

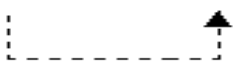

nominative case, EPP

After: [tp agent. probe $\quad\left[T^{\prime} T^{0}\right.$.GOAL [v1P .....

In transitive and ditransitive sentences as in (18a) and (18b) above, patient/theme originates as complements of the head $\mathrm{V}$. The head $\mathrm{V}$ checks structural accusative case to the patient/theme as in (20).

(20) Before: [vp [v'V.GOAL patient/theme.probe $]]$

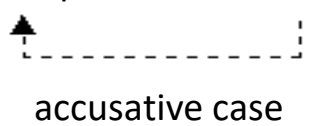

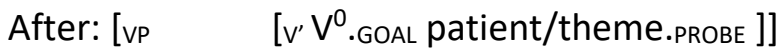

In a ditransitive sentence as in (18c) above, the goal/recipient originates at lower $\left[\mathrm{spec}, \mathrm{v}_{2} \mathrm{P}\right.$ ] and $\mathrm{v}$ checks lexical case features the goal/recipient as in (21). 
(21) Before: [v2P goal. Probe $\left[\mathrm{vz}^{\prime} \mathrm{v}^{0}\right.$. GOAL $\left.\left.\ldots\right]\right]$

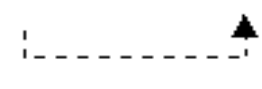

Lexical case

After: [v2P goal.PROBE $\left.\left[\mathrm{vz}^{\prime} \mathrm{v}^{0} \cdot \mathrm{GOAL} . ..\right]\right]$

In a psych-predicate as in (3c) in section 2.1 repeated in (22), experiencer gets demoted to achieve object-like properties. In Santali, the object-like property is object agreement. See Section 2.2 for the typological analysis of object-like property. Hence, it originates at [spec, $\mathrm{v}_{1} \mathrm{P}$ ] and $\mathrm{v}$ checks lexical case features to the experiencer as in (23a). On the other hand, the theme originates as a complement of $V$ and moves to [spec, TP] as in (23b). Consequent to movement, $\mathrm{T}^{0}$ checks nominative case to the theme as in (18).

(22) baha $_{i}$ raban nam-akad-e(y) i-a (Santali)

Baha.experiencer cold.theme have-PRF:A-OM-FIN

'Baha caught cold.'

(23a) Before: [TP $\left[\mathrm{T}^{\prime} \mathrm{T}^{0} . \mathrm{GOAL} \ldots\left[\mathrm{v} 1 \mathrm{P}\right.\right.$ experiencer.PROBE $\left.\left.\left[\mathrm{v} 1^{\prime} \mathrm{v}^{0} \mathrm{GOAL}[\mathrm{v} 2 \mathrm{P} \ldots[\mathrm{vP} \ldots]]\right]\right]\right]$

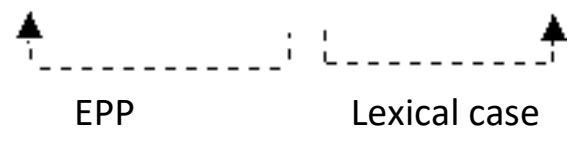

After: [TP $\left[\mathrm{T}^{\prime} \mathrm{T}^{0}\right.$. .GOAL ... [v1P experiencer.PROBE $\left[\mathrm{v}^{\prime} \mathrm{v}^{0} \mathrm{GOAL}\left[\mathrm{v} 2 \mathrm{P} \ldots\left[\begin{array}{lll}\mathrm{vP} & \ldots & ]\end{array}\right]\right]\right]$

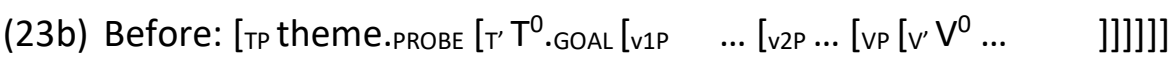

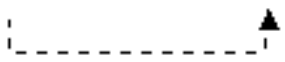

Nominative case, EPP

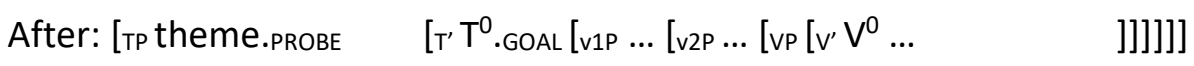

\subsection{Step 3}

Arguments that trigger object agreement do not possess one type of case. They vary with respect to case. Such dissociation of agreement and case is due to two reasons. Firstly, arguments occupy different positions within VP. And secondly, the head agrees with an argument and the argument does not receive case-features from the same head. In contrast, arguments with subject agreement obligatorily have nominative case indicating association of agreement and case. This happens because the head that participates in subject agreement also participates in nominative case. Thus, there is both association as well as a dissociation of agreement and case in Santali. Keeping in view the (diss-)association, we adopt Bhatt's (2005) AGREE which is an extension of 
Chomsky's (1998, 1999, 2000) Agree ${ }^{17}$. Below, we elaborate feature checking of agreement in Santali.

In subject agreement as in (2a) in section 2.1 and repeated in (24) below, tense functions as a probe with unvalued, uninterpretable phi-features, and it searches for a DP which is a goal with interpretable phi-features. Agent in intransitive, transitive and ditransitive sentences, is the goal. Tense checks the phi-features with the agent located at [spec, TP] to trigger subject agreement as in (25).

gidra ${ }_{i} \quad$ udgorop-kan-a-yi
child.agent sweat-COP.PST-FIN-SM

'The child was sweating.'

(25) Before: [tPagent.gOAL [ $\mathrm{T}^{\prime} \mathrm{T}^{0}$.PROBE $\left.\left.[\mathrm{v1P} \ldots . .].\right]\right]$

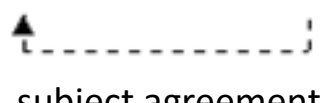

After: [tp agent.gOAL [ $\left[\mathrm{T}^{\prime} \mathrm{T}^{0}\right.$. PROBE $[\mathrm{v} 1 \mathrm{P}$......]]]

In object agreement of a patient, a goal/recipient and an experiencer as in (1), (4b) and (3c) in section 2.1 repeated in (26), V functions as probe with uninterpretable unvalued phi-features. Patient and goal/recipient as in (26b) and the experiencer as in (26c) function as goalss with interpretable object agreement features. $V$ searches for its nearest DP within the verbal complex and checks object agreement as in (27).

(26a) arel $_{i}$ uni $_{j} \quad$ nel-ked-e $e_{j}(y) a-y_{i} \quad$ (Santali)

Arel him.patient see-PST:A-OM-FIN-SM

'Arel saw him.'

(26b) baha $_{i} \quad$ arel gidra-kin ema-t-kin $_{j}-a_{-} y_{i} \quad$ (Santali)

Baha.SUBJ Arel.goal child-dual.patient give-PST:A-OM-FIN-SM

'Baha gave the (two) children to Arel.'

\footnotetext{
${ }^{17}$ Chomsky's Agree states that, the head $\mathrm{T}^{0}$ functions as an unvalued, uninterpretable $\varphi$-PROBE and searches for the closest GOAL, such as a DP possessing its own interpretable features, in order to enter into an Agree relationship. Once the head $\mathrm{T}^{0}$ finds a DP, $\mathrm{T}^{0}$ gets a value from the DP, as a result the uninterpretable features of $\mathrm{T}^{0}$ are erased. Simultaneously, case is checked in a similar manner. However, in case checking, DP functions as a PROBE with unvalued, uninterpretable case features and searches for a functional verbal head, a GOAL with interpretable case features. The feature interaction of agreement and case take place simultaneously. Once a DP is valued by case-features, the DP becomes inactive. An inactive GOAL is ineligible to value its $\varphi$ features of agreement to a PROBE. Now, the difference between Agree and AGREE is that the GOAL is not inactive in AGREE. That is, a head agrees with an argument and the argument does not receive case-features from the same head.
} 
(26c) baha $_{i}$

$$
\text { raban }
$$

nam-akad-e $-a$

(Santali)

Baha.experiencer cold.theme have-PRF:MID-OM-FIN

'Baha caught cold.'

(27a) Before: [vp [ $v^{\prime} V^{0}$.PROBE ]] patient.gOAL]

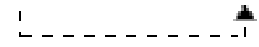

object agreement

After: [vp [ $v^{\prime} V^{0}$.PROBE patient.GOAL $\left.]\right]$

(27b) Before: [v2P goal. Probe [v2 v $^{0}$. GOAL...]]

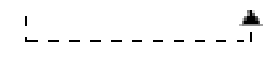

object agreement

After: [v2P goal.proBe [v2'v0.GOAL...]]

(27c) Before: [v1P experiencer.probe [v1' V.GOAL [v2P ... [vp

[ ] [ ] ] $]$

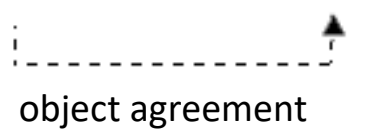

After: [v1P experiencer.Probe [v1' V.GOAL [v2P ... [vP ... ] ] ] ]

\subsection{Step 4}

Since SM is a Wackernagel element, it gets dislocated from the post-verbal position to the prosodically most prominent constituent through Prosodic Inversion (Halpern, 1992; Taylor, 1995) at PF. The Prosodic Inversion does not apply to OM since the OM does not possess a mechanism of movement similar to SM. Therefore, it remains in the same position where it originates. At LF, SM originates as an affix post-verbally. Due to prosodic inversion, SM moves to a constituent to the left of the verb as in (28a). In case SM occurs more than once within the utterance, it realizes as an affix post-verbally and consequently, it moves to leave a copy, where ever SM occurs within the utterance as in (28b). XP in (28) indicates any constituent in a preverbal position.

(28a) Before: [xp $\left.\mathrm{X}^{0}\left[\mathrm{vP}^{\mathrm{O}}=\mathrm{SM}\right]\right]$

After: $\left[\mathrm{xP}^{\mathrm{O}}=\mathrm{SM}\left[\mathrm{VP} \mathrm{V}^{0}\right]\right]$

(28b) Before: [xp $\left.\left.\mathrm{X}^{0}\left[\mathrm{vp}^{0}=\mathrm{SM}\right]\right]\right]$

After: [ $\left.\mathrm{XP}^{\mathrm{X}} \mathrm{X}^{0}=\mathrm{SM}\left[\mathrm{vP}_{\mathrm{P}} \mathrm{V}^{0}=\mathrm{SM}\right]\right]$ 


\section{Conclusion}

In this paper, we show that the pronominal number markers that indicate arguments of a sentence in Santali have properties of a clitic as well as an affix. Most of the properties of a clitic have already been identified in Kidwai (2005). In this paper, we identified the properties of an affix with the help of a typological analysis and the application of diagnostic tests. Kidwai's analysis that show properties of a clitic are the following.

1.The SM has a high degree of selection of hosts such as nouns, postpositions, negation, light verb etc.

2. Unexplained gaps corresponding the $\mathrm{SM}$ or $\mathrm{OM}$ are absent. Idiosyncratic semantics do not exist.

3. Allomorphy of the markers is absent.

4. The SM can move.

5. The marker attaches the morphemes indicating functional categories.

Additionally, we stated one more property of a clitic that the markers do not occur when the nouns are inanimates.

A typological observations of Khasi, Santali, Hindi-Urdu and Telugu show that some properties of a clitic resemble Khasi, where Khasi has a preverbal SM similar to Santali. Some properties of an affix resemble Hindi-Urdu and Telugu such as the post-verbal occurrence of SM. Observation of DO, 10 and NNS show that the object-like properties of these arguments display morphological variations among these languages. However, they have a common underlying configuration that enables arguments to possess object-like properties. Another commonality determining the property of an affix is the obligatory co-occurrence of a nominative case and subject marking in Santali, HindiUrdu and Telugu. Looking at common operations, we assumed that there can be some operations in Santali similar to non-Austro-Asiatic languages, which allow a marker to be an affix. The obligatorily co-occurrence of nominative case and subject marking indicates association of agreement and case. In contrast, $\mathrm{OM}$ and case show dissociation since the OM does not correspond to one particular case.

An application of diagnostic tests show the following properties of an affix.

1. The subject marker and the object marker are sensitive to case similar to an affix.

2. In other words, SM occurs only with nominative case marked argument and OM occurs only with arguments such as DO, 10 and NNS, which are the arguments that possess the properties of an object.

3. The $\mathrm{OM}$ of an $\mathrm{IO}$ in a ditransitive sentence is not realized irrespective of its animate feature, since the $\mathrm{OM}$ is sensitive to case along with animacy. 
4. The pronominal number markers do not function as potential interveners preventing binding relations. This in turn indicates that the pronominal number markers do not function like pronouns.

Keeping in view the distribution of pronominal number markers, we analysed the operations of agreement and case in four steps. Step 1 showed that the inanimates exist lower in the DP and animates move from lower $\mathrm{N}^{0}$ to $\mathrm{D}^{0}$ for further process of agreement. Step 2 showed case checking of the arguments. Step 3 presented feature checking of subject and object agreement. Step 4 dealt with Prosodic Inversion depicting dislocation of SM.

\section{Appendix}

Below are the pronouns and the corresponding pronominal number markers.

The personal pronouns (Full/Free forms) of Santali:

\begin{tabular}{llllll}
\hline Person & singular & Dual & Plural & & \\
\hline & & INCL & EXCL & INCL & EXCL \\
\hline First & in & alan & alin & abo & ale \\
Second & am & & aben & & ape \\
Third & $a c^{\prime}$ & & akin & & ako \\
& uni & & unkin & & onko \\
\hline
\end{tabular}

(Ghosh, 2008, p. 41)

Short/Bound forms of personal pronouns:

\begin{tabular}{llllll}
\hline & Singular & Dual & \multicolumn{3}{c}{ Plural } \\
\cline { 3 - 5 } & & INCL & EXCL & \\
\hline First & $-n($ in) & $-l a n$ & $-l i n$ & $-b o n$ & $-l \varepsilon$ \\
Second & $-m$ & & $-b e n$ & & $-p \varepsilon$ \\
Third & $-e$ & & $-k i n$ & & $-k o$ \\
& & & & & \\
\hline
\end{tabular}

(Ghosh, 2008, p. 54) 


\section{Abbreviations}

3 : Third person

A : Active

ACC : Accusative

AGR : Agreement

APP : Applicative

APP : Applicative

COP : Copula

DAT : Dative

DEF : Definite

DO : Direct Object

F/FEM : Feminine

FIN : Finite

GEN : Genitive

HAB : Habitual

IO : Indirect Object

M : Masculine

MID : Middle

NNS : Non-Nominative Subject

NOM : Nominative

NOM OBJ : Nominative Object

OM : Object Marker

PRF : Perfect

PL : Plural

PRES : Present

PROG : Progressive

PST : Past

REFL : Reflexive

SG : Singular

SM : Subject Marker

TAM : Tense Aspect Mood

VREF : Verbal reflexive 


\section{References}

Anderson, G. D. S. (2007). The Munda Verb: Typological Perspectives. Berlin-New York: Mouton De Gruyter.

Baker, M. (2015). Case (No. 146). Cambridge: Cambridge University Press.

Baker, M., \& Kramer, R. (2016). Doubling clitics are pronouns: Reduce and interpret (Manuscript). Rutgers University and Georgetown University.

Bhatt, R. (2005). Long-distance agreement in Hindi-Urdu. Natural Language and Linguistic Theory, 23, 757-807. Retrieved from at https://people.umass.edu/bhatt/papers/bhattIda-nllt05.pdf.

Bhattacharya, T. (1999). The structure of the Bangla DP. Department of Linguistics (Doctoral Dissertation). University College London. Accessed at http://people.du.ac.in/ tanmoy/papers/Tanmoy_UCL_PHD.pdf

Chomsky, N. (1998). Minimalist Inquiries: The Framework, No. 15. In MIT Occasional Papers in Linguistics, Massachusetts: MITWPL.

Chomsky, N. (1999). Derivation by Phase, No. 18. In MIT Occasional Papers in Linguistics, Cambridge, Massachusetts: MITWPL.

Chomsky, N. (2000). Minimalist inquiries, the framework. In R. Martin, D. Michaels \& J. Uriagereka (Eds.), In honour of Howard Lasnik. Step by step: Essays on minimalist syntax (89-155). Massachusetts: MIT Press.

Comrie, B. (2005). Alignment of case marking of full noun phrases. In M. Haspelmath, M. Dryer, D. Gil and B. Comrie (Eds.), The world at language structures (398-403). New York: Oxford University Press.

Corbett, G. G. (2006). Agreement. Cambridge: Cambridge University Press.

Davison, A. (2004). Structural case, lexical case and the verbal projection. In Clause structure in South Asian languages, 199-225. Springer, Dordrecht. Retrieved from https://link.springer.com/chapter/10.1007/978-1-4020-2719-2_7

Ghosh, A. (2008). Santali. In Anderson (ed.), The Munda Languages. 434-507. New York: Routledge.

Givón, T. 1976. Topic, pronoun and grammatical agreement. In Charles Li (ed.), Subject and Topic (149-188). New York: Academic Press.

Halpern, A. L. (1992). Topics in the placement and morphology of clitics (Doctoral dissertation). Stanford University.

Harizanov, B. (2014). Clitic doubling at the syntax-morphophonology interface. Natural Language \& Linguistic Theory, 32(4), 1033-1088.

Hock, H. H. (2013). Backernagel is Wackernagel Lite. On the "P-Minus 2" Clitics of Santali. Lingua posnaniensis, 55(2), 67-75.

Kidwai, A. (2005). Santali 'Backernagel' Clitics: Distributing Clitic Doubling. In R. Singh (ed.), The Yearbook of South Asian Languages and Linguistics (189-207). Berlin: Mouton De Gruyter.

Kramer, R. (2014). Clitic doubling or object agreement: the view from Amharic. Natural Language \& Linguistic Theory, 32(2), 593-634. Retrieved from http://faculty.georgetown.edu/rtk8/Clitic\%20Doubling\%20or\%200bject\%20Agreement.pdf 
Leslau, W. (1995). Reference grammar of Amharic. Wiesbaden: Otto Harrassowitz Verlag.

Matushansky, O. (2006). Head movement in linguistic theory. Linguistic Inquiry, 37: 69-109.

Mavrogiorgos, M. (2010). Clitics in Greek: A minimalist account of proclisis and enclisis. Amsterdam/Philadelphia: John Benjamins Publishing.

Nagaraja, K. S. (1993). Agreement in Khasi and Munda languages. Bulletin of the Deccan College Research Institute, 53, 271-276. Accessed at https://www.jstor.org/stable/42936449.

Neukom, L. (2001). Santali. Muenchen: Lincom Europa.

Nevins, A. (2011). Multiple agree with clitics: Person complementarity vs. omnivorous number. Natural Language \& Linguistic Theory, 29, 939-971.

Osada T. (2008). Mundari. In Anderson (ed.), The Munda Languages. 99-164. New York: Routledge.

Siewierska, A. (2005). Alignment of verbal person marking. In M. Haspelmath, M. Dryer, D. Gil, and B. Comrie (eds.), The world atlas of language structures (406-409). New York: Oxford University Press.

Subbarao, K. V. (2012). South Asian languages: A syntactic typology. Cambridge: Cambridge University Press.

Suñer, M. (1988). The role of agreement in clitic-doubled constructions. Natural Language \& Linguistic Theory, 6: 391-434.

Taylor, A. (1995). The distribution of object clitics in Koine Greek. University of Pennsylvania Working Papers in Linguistics, 2(1), 7.

Thráinsson, H. (1979). On Complementation in Icelandic. New York: Garland.

Woolford, E. (2006). Lexical case, inherent case, and argument structure. Linguistic inquiry, 37(1), 111-130. 